Article

\title{
Impacts of Intermittent Water Supply on Water Quality in Two Palestinian Refugee Camps
}

\author{
Shatha Alazzeh ${ }^{1}$, S. E. Galaitsi ${ }^{2}$, Amahl Bishara ${ }^{3}$, Nidal Al-Azraq ${ }^{4}$ and John L. Durant ${ }^{2, *}$ (i) \\ 1 Department of Earth and Science, Al Quds University, Jerusalem 20002, West Bank, Palestine; \\ shatha.alazzeh@gmail.com \\ 2 Department of Civil \& Environmental Engineering, Tufts University, Medford, MA 02155, USA; \\ stephanie.galaitsi@gmail.com \\ 3 Department of Anthropology, Tufts University, Medford, MA 02155, USA; amahl.bishara@tufts.edu \\ 4 1for3.org, Winchester, MA 01890, USA; nidal.alazraq@1for3.org \\ * Correspondence: john.durant@tufts.edu; Tel.: +1-617-627-5489
}

Received: 30 January 2019; Accepted: 27 March 2019; Published: 31 March 2019

\begin{abstract}
We investigated the quality of treated drinking water in Aida Camp and Alazzah Camp, two Palestinian refugee camps in the West Bank. Water supply in the two camps is intermittent: Water deliveries are first stored in a centrally located community tank before being pumped through distribution networks to users, who then store the water in rooftop tanks. Between March 2016 and June 2017, we examined water quality within the distribution system in the camps, testing 520 samples in Aida Camp and 198 samples in Alazzah Camp for total coliforms, Escherichia coli (E. coli) bacteria, and residual chlorine. We observed deterioration in water quality in both camps, but the deterioration was more pronounced in Aida Camp where 2.5\% of community-tank samples, 5.0\% of network samples, and 10\% of rooftop-tank samples contained one or more colonies (per $100 \mathrm{~mL}$ ) of total coliform bacteria. In Alazzah Camp, 3.7\% of community-tank samples, $2.5 \%$ of network samples, and 5\% rooftop-tank samples contained one or more colonies (per $100 \mathrm{~mL}$ ) of total coliform bacteria. E. coli was detected in two samples from Aida Camp and one sample from Alazzah Camp. In both camps, average residual chlorine concentrations were higher in the community tanks than in rooftop tanks. The main factor influencing water quality deterioration in rooftop tanks in Aida Camp appears to be air temperature. We recommend more systematic water testing in the camps and greater transparency in reporting test results to camp residents.
\end{abstract}

Keywords: drinking water quality; intermittent water supply; refugee camps; total coliforms; E. coli; residual chlorine

\section{Introduction}

Water consumption by Palestinians in the Israeli-occupied West Bank, where water supplies are limited [1], averages $70 \mathrm{~L}$ per capita per day (lpcd), well below the World Health Organization (WHO) minimum standard of 100 lpcd [2]. Water shortages are particularly acute in Palestinian refugee camps where water is supplied intermittently. In many of the camps, drinking water deliveries are first stored in a large centrally located tank, before being pumped through the camp water distribution network to homes, businesses, schools, and other users, who then store the water in rooftop tanks. The rooftop tanks allow users more continuous access to water; however, the longer the period between water deliveries to the camp, the longer users tend to hold water in reserve in the rooftop tanks. This often leads to water quality deterioration.

While problems related to water shortages and intermittent supplies in the West Bank have been documented [3-5], less is known about water quality and connections between poor water quality 
and human health. In 2011, the Palestinian Water Authority (PWA) reported that $16 \%$ of 8500 water samples from the taps of end users across the West Bank were contaminated with coliform bacteria. Similarly, in a 2015 report, the Environmental Health Department of the Palestinian Ministry of Health observed that $16 \%$ of water network samples from across the West Bank failed bacteriological testing [6]. Neither of these two studies reported disaggregated data; therefore, temporal and spatial patterns of contamination cannot be discerned. We found two papers that reported the connections between water quality and public health in Palestinian refugee camps: Mourad [7] found a correlation between diarrhea rates and drinking water source in the Nuseirat refugee camp in Gaza, and Issa et al. [8] reported that Palestinians living in the Kulandia refugee camp had a general lack of awareness of the relationship between diarrheal illness and hygiene.

We were interested in studying drinking water quality in two refugee camps in the Bethlehem governorate: Aida Camp and Alazzah Camp. Both camps were founded in 1950. Although the United Nations Relief and Works Agency (UNRWA) performs routine water testing within the camps, the results are not publicly available. Our objectives were to (1) measure water quality indicators in different kinds of water in the two camps (community tanks, network pipes, rooftop tanks), and (2) characterize household water quality differences in terms of spatial and temporal factors, including elevation and distance of water sample collection points relative to the community tanks, temperature, time since last water delivery to the camps, and residual disinfectant concentration.

We measured total coliform and E. coli bacteria in water samples. Coliform bacteria derive from the gut and intestines of warm-blooded animals. While the majority of coliforms are not pathogenic, their presence in water may indicate the presence of disease-causing microorganisms [9]. Consumption of water contaminated with pathogenic microorganisms can cause diarrhea, cramps, nausea, headaches, or other symptoms. These pathogens pose special health risks for infants, young children, and people with compromised immune systems [10]. According to the World Health Organization (WHO), E. coli and total coliform bacteria should be undetectable in 100-mL treated drinking water samples (zero colony forming units (CFU) /100 mL) [11].

We also measured residual chlorine in water samples. The water in the camps is treated with chlorine before entering the distribution system. WHO guidelines indicate that free residual chlorine concentration of $0.2-0.8 \mathrm{mg} / \mathrm{L}$ should be maintained in the water distribution system [12]. As treated water moves through the distribution system, the concentration of free chlorine residual can decrease due to evaporation and reaction with inorganic and organic impurities in water (e.g., dissolved iron, ammonia, dissolved organic material, bacteria, viruses), as well as pipe and tank walls [13-15].

\section{Materials and Methods}

\subsection{Study Areas}

Aida Camp is $0.071 \mathrm{~km}^{2}$ in area and has a population of 3150 registered refugees [16]. Alazzah Camp, formally Beit Jibrin Camp, is $0.027 \mathrm{~km}^{2}$ in area and has a population of 1337 registered refugees [16]. Both camps are located in the northeastern part of Bethlehem. Both camps contain fully paved roads that are lined with three- to four-story residential buildings and interspersed with businesses, mosques, and schools. A main feature of Aida Camp is that much of it is situated on an 85-m-high hill. The community water tanks are at the base of the hill. There are two tanks immediately adjacent to one another; the total volume of the tanks is $100 \mathrm{~m}^{3}$. After water is delivered to the community tanks by the Bethlehem Water Supply and Sewerage Authority, it is pumped throughout the camp, with lower elevation homes and buildings being served first. Because homeowners at the top of the hill are only able to fill their tanks after tanks at lower elevations are filled, there have been complaints of inequitable distribution of water within the camp. In contrast, Alazzah Camp's community tank $\left(20 \mathrm{~m}^{3}\right)$ is located at the highest point in the camp, and there are fewer complaints of topography-related water distribution inequity. 


\subsection{Water Sample Collection}

Samples from three different types of water infrastructure were collected in each camp: Community-tank water, distribution-network water, and rooftop-tank water. Community-tank water samples were collected from a publicly accessible spigot connected to the tanks. Samples from the distribution networks were collected from the pressure relief valves on pumps used to deliver water to the rooftop tanks. Samples of rooftop-tank water were collected from faucets inside individual homes. The sampling method combined quota sampling and random sampling. We divided Aida camp into four quadrants of roughly equal size, and randomly selected residential addresses for sampling within each quadrant: Northeast ( $n=106$ addresses), southeast $(n=74$ addresses), southwest $(n=55$ addresses), and northwest ( $\mathrm{n}=44$ addresses), i.e., 279 total addresses or $44 \%$ of residential buildings in the camp. This ensured that the different quadrants of the camp were represented and also that sampling locations within the quadrants were randomly selected. In Alazzah Camp, we randomly selected 100 residential addresses (50\% of the total) for sample collection. In both camps, where there were multi-family houses at a single address, we randomly selected which household to test.

Water samples were collected in sterilized $125-\mathrm{mL}$ polypropylene bottles that were double-rinsed with distilled and deionized water and then triple-rinsed in the field with source water (we have found this rinsing protocol removes residual disinfectant to non-detect concentrations (unpublished data)). Just prior to sample collection, metal taps were disinfected with a direct flame for ten seconds and plastic taps were wiped with alcohol-soaked tissue paper. Source water was then run through the taps for five seconds before sample collection. Samples were transported to the laboratory in a cooler, containing freezer packs. Water sampling was performed between May 2016 and June 2017 in Aida Camp and between March 2016 and June 2017 in Alazzah Camp. Sampling was conducted for 45 days in Aida Camp and 33 days in Alazzah Camp. On each sampling day, we collected, on average, 11 samples in Aida Camp and 6 samples in Alazzah Camp. Sampling was conducted in all months of the study period and on all days of the week. All sampling was performed between the hours of 10:00 and 12:00. At the time of sample collection, the latitude, longitude, and elevation of each home was measured with a GPS, and a survey was administered to an adult resident living at each house. The survey contained questions about the material and capacity of rooftop water storage tanks, chlorination practices or other measures taken by the household to protect water quality, the date of the last water delivery to the tanks, and whether members of the household had recently experienced sickness like vomiting or diarrhea.

\subsection{Bacteria Testing}

The water samples were tested for bacteria in the laboratory within three hours of collection. Each sample (125 mL) was filtered through a sterile 0.45 -micron pore size membrane filter (Millipore, Burlington, MA, USA). The filters were then placed in sterile petri dishes (Millipore, Burlington, MA, USA), containing growth media ( $2 \mathrm{~mL}$ of m-ColiBlue24; Millipore, Burlington, MA, USA) and incubated at $35{ }^{\circ} \mathrm{C}$ for $22 \pm 2 \mathrm{~h}$. Immediately after incubation, the membrane filters were visually examined for the presence of coliform colonies. Glossy, round, dark blue colonies were counted as E. coli colonies, and glossy, round, dark red colonies were counted as other coliforms. Total coliforms were calculated by adding together the number of blue and red colonies. A negative control $(100 \mathrm{~mL}$ of bottled water, purchased from a local grocery store) and a positive control ( $<1 \mathrm{~mL}$ of toilet water, collected within the camp and diluted with $99 \mathrm{~mL}$ of tap water) sample were analyzed on each day that drinking water samples were analyzed-46 days in Aida Camp and 34 days in Alazzah Camp. A sample was considered positive if it contained one or more colony-forming units per $100 \mathrm{~mL}$ of water (i.e., $\geq 1 \mathrm{CFU} / 100 \mathrm{~mL}$ ).. Total coliform bacteria were not detected in any of the negative controls, and coliform colonies were too numerous to count in the positive controls (as expected). 


\subsection{Residual Chlorine Testing}

Residual chlorine concentration was measured as free available chlorine in situ, in samples of household and community tap water using a LaMotte 1200 portable spectrophotometer (Fisher Scientific, Waltham, MA, USA). After water samples were collected for bacteria testing, an additional sample was collected in a cleaned 10-mL glass colorimeter tube. For each analysis, the tube was first triple-rinsed with the source water, filled to the $10-\mathrm{mL}$ line with water, and then wiped with tissue paper to remove fingerprints and other debris. Next, a 1-g tablet of buffered diethyl-p-phenylenediamine indicator (DPD) was added, and the tube was then capped, shaken for 20-30 s (until the reagent tablet dissolved), and then rotated slowly five times to promote reaction between free available chlorine in the water DPD. Finally, the tube was inserted into the spectrophotometer and absorbance was measured. The concentration range reported for this method is $0-4.00 \mathrm{mg} / \mathrm{L}$ and the detection limit is $0.05 \mathrm{mg} / \mathrm{L}$, which is the minimum concentration that can be measured with $99 \%$ confidence [17]. External calibration was performed with different chlorine concentrations $(0.00,0.02,0.05,0.10,0.20$, $0.50 \mathrm{mg} / \mathrm{L}$ ) at the beginning of each day of water testing.

\section{Results}

\subsection{Bacterial Testing Results}

We observed that drinking water delivered to the two camps was generally of high quality, as indicated by coliform bacteria measurement: In Aida Camp, 2 of 39 samples (5.1\%) collected from the community tank over a 14-month period contained bacteria, and in Alazzah Camp, only 1 of 23 samples $(4.3 \%)$ collected from the community tank over a 16-month period contained bacteria (Table 1). Similarly, there appeared to be no change in the quality of water as it moved through the distribution systems of the two camps: 5.0\% (10/200) of samples from network pipes in Aida Camp and 2.7\% (2/75) of samples from network pipes in Alazzah Camp contained bacteria. In contrast, in rooftop-tank water in Aida Camp, we observed much higher amounts of bacterial contamination compared to community-tank water and network water.

Table 1. Summary of Bacterial Testing Results ${ }^{1}$.

\begin{tabular}{|c|c|c|c|}
\hline \multirow{2}{*}{ Water Source } & \multirow{2}{*}{$\begin{array}{c}\text { \# of Water } \\
\text { Samples Tested }\end{array}$} & \multicolumn{2}{|c|}{ \# of Samples Containing Bacteria } \\
\hline & & Total Coliform & E. coli \\
\hline \multicolumn{4}{|c|}{ Aida Camp } \\
\hline Community tank & 39 & $2(5.1 \%)$ & 0 \\
\hline Pipe network & 200 & $10(5.0 \%)$ & $1(0.5 \%)$ \\
\hline Rooftop tank ${ }^{2}$ & 281 & $28(10.0 \%)$ & $1(0.3 \%)$ \\
\hline Totals & 520 & $40(7.7 \%)$ & $2(0.4 \%)$ \\
\hline \multicolumn{4}{|c|}{ Alazzah Camp } \\
\hline Community tank & 23 & $1(4.3 \%)$ & 0 \\
\hline Pipe network & 75 & $2(2.7 \%)$ & 0 \\
\hline Rooftop tank ${ }^{3}$ & 100 & $4(4.0 \%)$ & $1(1.0 \%)$ \\
\hline Totals & 198 & $7(3.5 \%)$ & $1(0.5 \%)$ \\
\hline
\end{tabular}

\footnotetext{
${ }^{1}$ The data used to prepare this table are also depicted in Figures $1-5 .{ }^{2}$ A sample was considered positive if it contained $\geq 1$ colony forming unit per $100 \mathrm{~mL}$ of water. Percentage of positive samples are indicated parenthetically.

${ }^{3}$ Samples of rooftop-tank water were collected inside homes, typically from the kitchen sink. \# = Number.
}

In Aida Camp, 28 of 281 (10\%) samples from rooftop tanks were contaminated with coliform bacteria and one rooftop-tank sample also contained E. coli (Table 1). These results strongly suggest that deterioration in water quality in Aida Camp occurred within rooftop tanks. In Alazzah Camp, where just 4 out of 100 samples (4\%) from rooftop tanks were contaminated, we did not observe a deterioration in rooftop-tank water, relative to community tank and network water (Table 1). Overall, 
we observed higher contamination in Aida Camp compared to Alazzah Camp. Of the 520 water samples collected in Aida Camp, 40 (7.7\%) tested positive for total coliforms, including one pipe network and one rooftop-tank sample that also tested positive for E. coli; and of the 198 samples collected in Alazzah Camp, seven (3.5\%) tested positive for total coliforms, including one rooftop-tank sample that also tested positive for E. coli (Table 1).

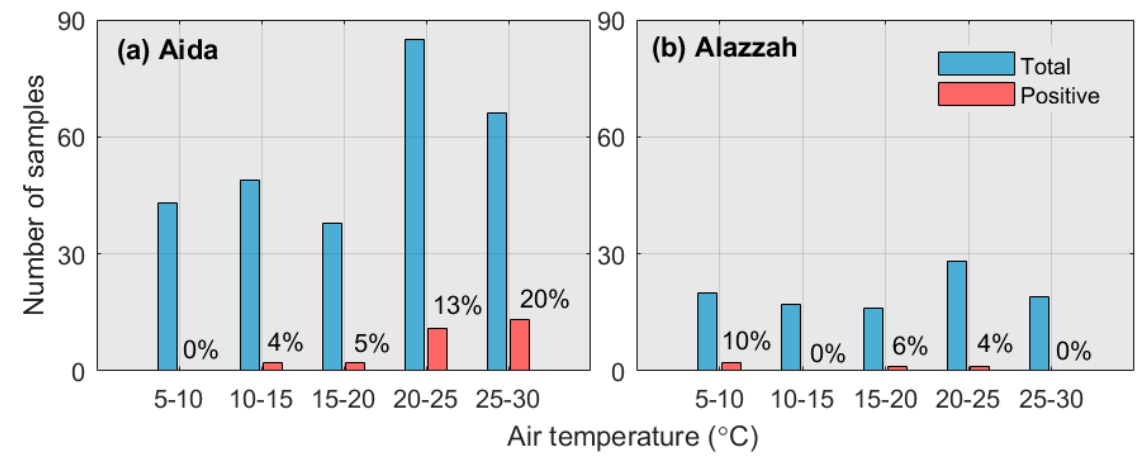

Figure 1. Relationship between air temperature and rooftop-tank water testing results for (a) Aida Camp and (b) Alazzah Camp. Air temperature values represent the 72-h average preceding the time of sample collection; averages were calculated with data available for Jerusalem from timeanddate.com. Percentage (\%) of total samples in each temperature group that tested positive are shown next to the bars.
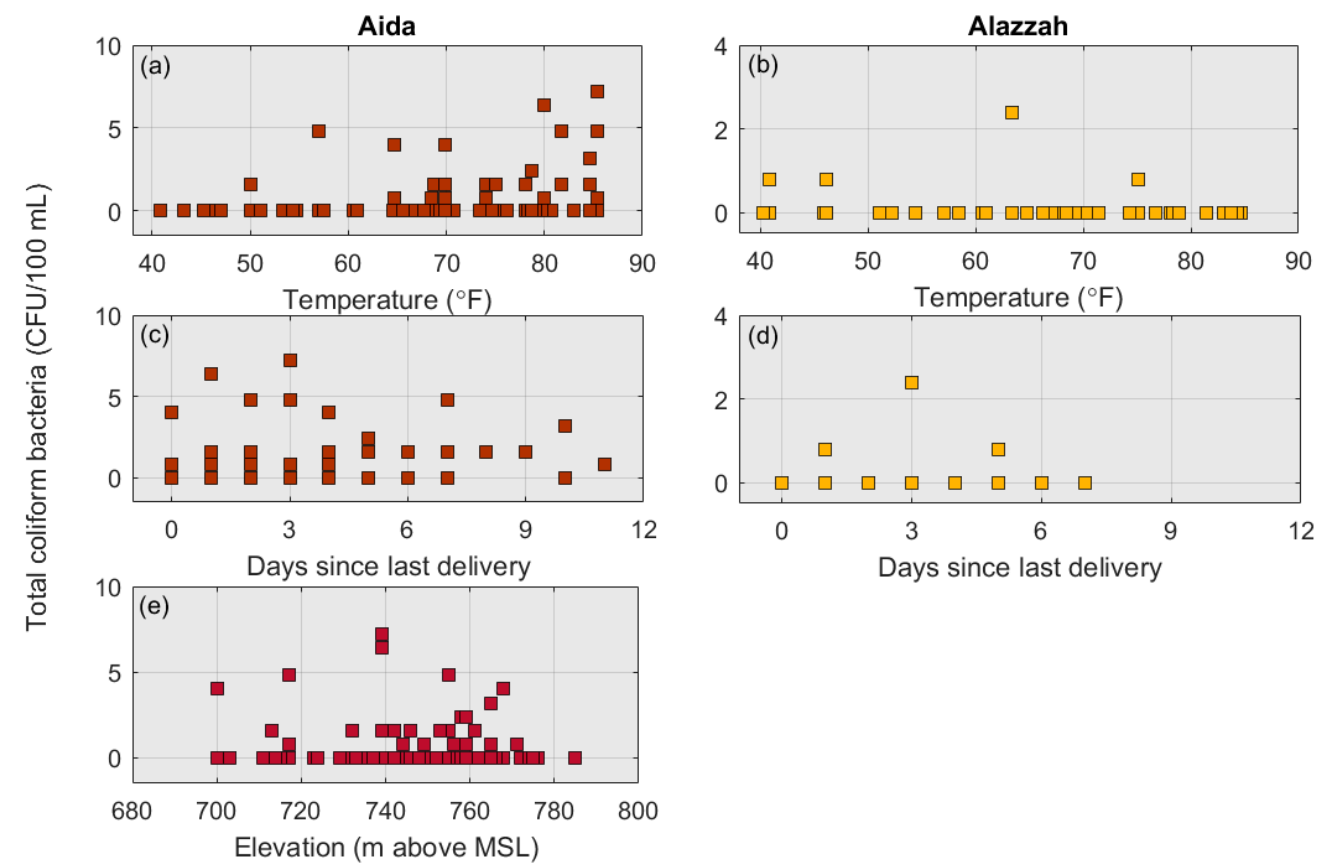

Figure 2. Scatter plots of total coliform bacteria versus (a),b) air temperature, $(\mathbf{c}, \mathbf{d})$ days since last water delivery to Aida Camp and Alazzah Camp, and (e) house elevation (Aida Camp only) for rooftop-tank samples. See Appendix A for regression statistics.

In general, the samples that tested positive in each camp were lightly to moderately contaminated with coliform bacteria. In the 28 samples from Aida Camp that were positive, 13 samples contained between three and nine $\mathrm{CFU} / 100 \mathrm{~mL}$ and the remainder contained just one or two CFU/100 mL. In the seven samples from Alazzah Camp that were positive, one sample contained three CFU/100 mL and the remainder contained just one CFU $/ 100 \mathrm{~mL}$. All the results were shared with the residents of Aida and Alazzah Camps: Individual residents were notified if coliform bacteria were found in their drinking water and de-identified result summaries were presented at community meetings. 


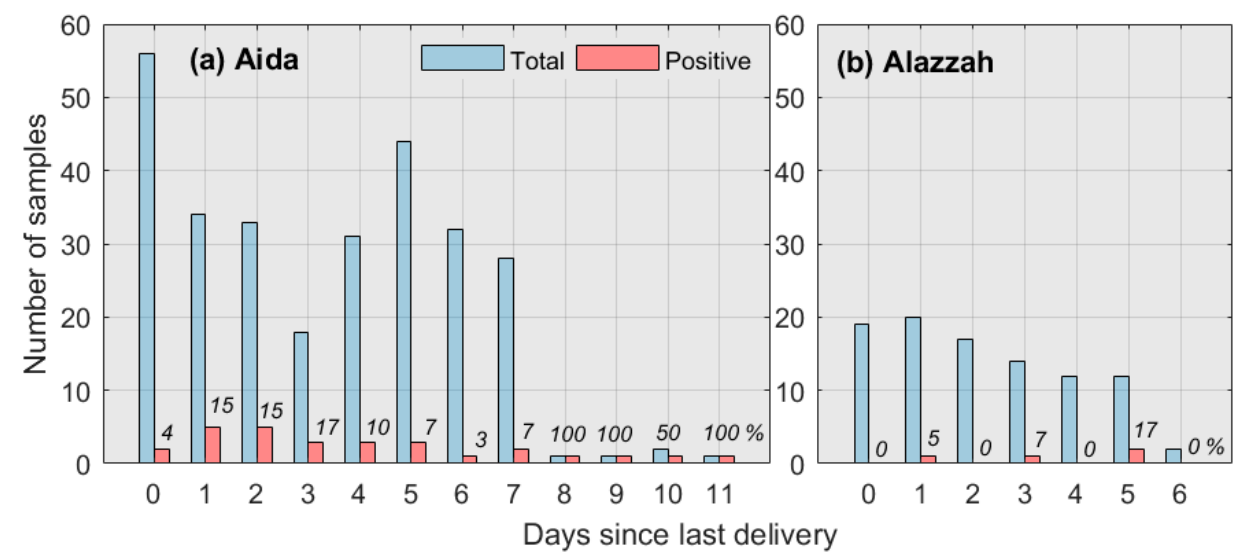

Figure 3. Rooftop-tank water testing results versus days since last water delivery to the tanks for (a) Aida Camp and (b) Alazzah Camp. Total number of samples tested for bacteria are shown with blue bars and the number of positive samples are shown with red bars. Days since last water delivery were self-reported by an adult member of the household at time of sample collection. Percentage of total samples in each day group that tested positive are shown next to the bars.

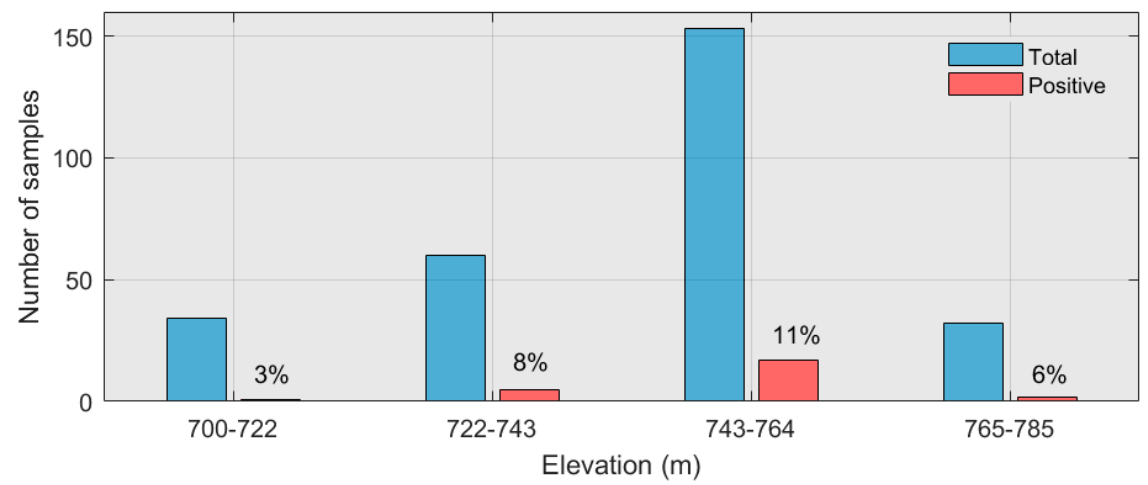

Figure 4. Relationship between ground elevation of residences in Aida Camp and rooftop-tank water testing results. Percentage (\%) of total samples in each elevation group that tested positive are shown next to the bars.
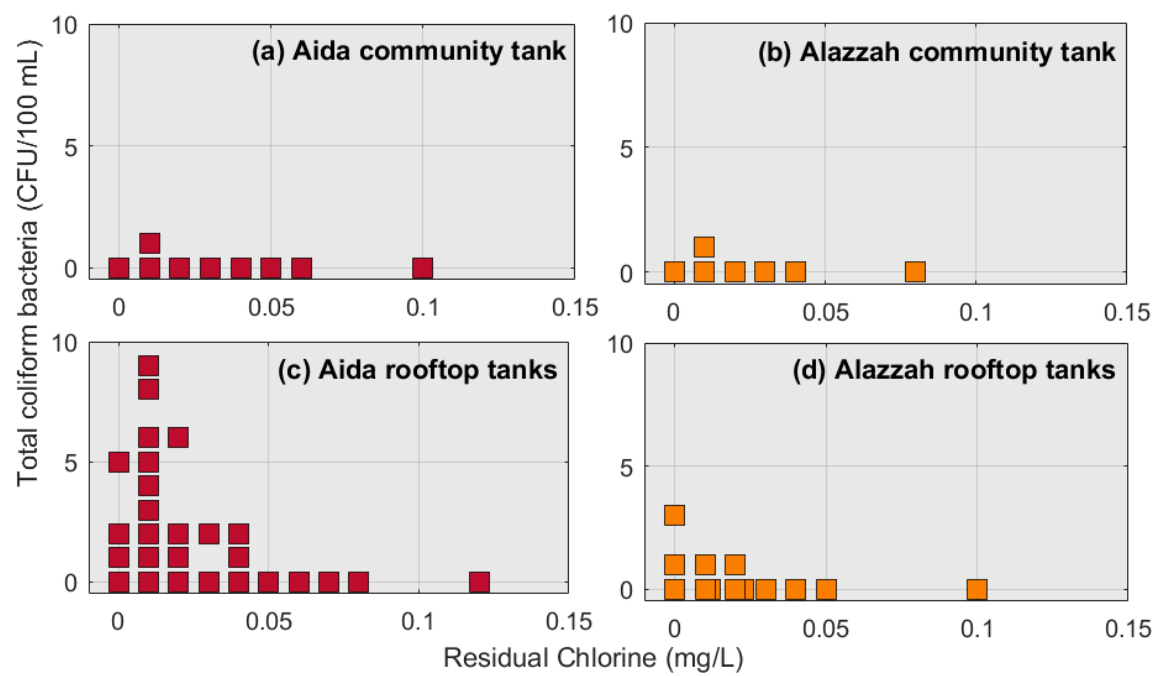

Figure 5. Relationship between bacteria levels (CFU concentrations) and residual free chlorine concentrations in $(\mathbf{a}, \mathbf{b})$ community- and $(\mathbf{c}, \mathbf{d})$ rooftop-tank water samples from Aida Camp and Alazzah Camp. See Figures A1 and A2 and Table A1 for regression statistics. 


\subsection{Factors Affecting Bacterial Testing Results}

We evaluated several factors-including ambient temperature, time since last water delivery to the camps, and residual chlorine concentration - to better understand their impacts on the quality of water in the rooftop tanks in each camp. In addition, in Aida Camp we evaluated elevation and proximity of water sample collection points, relative to the community tanks. In Aida Camp we found that ambient air temperature was the only factor that showed a trend in bacteria presence, while in Alazzah Camp, none of these factors were correlated with bacteria concentrations. As shown in Figure 1a, in Aida Camp, as ambient temperature (taken as the 72-h average air temperature prior to sample collection) increased, the fraction of rooftop-tank water samples that tested positive for total coliform bacteria also increased-from $0 \%$ when the air temperature was $5-10{ }^{\circ} \mathrm{C}$ to $4-5 \%$ when the air temperature was $10-20^{\circ} \mathrm{C}$, and to $13-20 \%$ when the air temperature was $>20^{\circ} \mathrm{C}$ (Figure 1). In contrast, in Alazzah Camp, the relationship between air temperature and bacteria contamination was not as clear: The highest percentage of contaminated samples was observed on days when the ambient temperature was lowest $\left(5-10^{\circ} \mathrm{C}\right)$, and none of the 19 samples collected when ambient temperatures were highest $\left(25-30^{\circ} \mathrm{C}\right)$ tested positive. Scatter plots of this data are shown in Figure 2.

The residents we surveyed reported that, on average, they receive water three times a month in summer and four times a month in winter. As shown in Figure 3, there was not a clear relationship between the number of days since the last reported delivery of water to the rooftop tanks and bacteriological water quality in either camp. Nonetheless, we observed that in samples from Aida Camp that were collected 8-11 days after the last water delivery $(n=5$ samples, each from a different tank), $80 \%$ were contaminated, while only $3.6 \%$ of samples collected on the same day that water was delivered to the camp were contaminated. Scatter plots of this data are shown in Figure 2.

Our results for Aida Camp suggest that there was an uneven distribution of contamination in rooftop tanks, depending on their proximity to the community tank. In the northeast quadrant, which is nearest to the community tank (the tank was $20 \mathrm{~m}$ north of the northern boundary of the quadrant), $5 \%(5 / 106)$ of rooftop-tank samples contained coliform bacteria, while in the other three quadrants, contamination was $2-3$ times higher (southeast $11 \%(8 / 74)$, southwest $16 \%(9 / 55)$, northwest $11 \%(5 / 44))$. We did not observe a clear relationship between the ground elevation of residences in Aida Camp and contamination in rooftop tanks (Figure 4). The percentage of samples that were contaminated increased with elevation for lower elevations; however, we did not observe this trend in samples collected at the highest elevations in the camp. For houses at 700-722 m, 0\% of the samples were contaminated, for houses at $722-743 \mathrm{~m}, 8 \%$ of samples were contaminated, for houses at 743-764 m, 11\% had contamination, whereas houses at the highest elevation $(764-785 \mathrm{~m})$ had $6 \%$ contamination.

When water is pumped from the community tank, which is near the lowest elevation in the camp $(728 \mathrm{~m})$, residences at the highest elevations generally receive water later than residences at lower elevations. However, households at different elevations generally reported the same number of days since water had last been delivered, though we did not determine whether differences in water delivery times were a matter of hours as opposed to days and whether households at higher elevations received the same amount of water as households at lower elevations. A scatter plot of this data is shown in Figure 2. Elevation data was not collected for Alazzah Camp because the community tank is at the highest point $(762 \mathrm{~m})$ in the camp.

In Aida Camp we tested 320 water samples (39 community tank and 281 rooftop-tank samples) for chlorine residual, and in Alazzah Camp we tested 124 samples (24 community-tank and 100 rooftop-tank samples) for chlorine residual. We found that in both camps, residual chlorine concentrations were, on average, higher in community tanks than in rooftop tanks. In Aida Camp, the average residual chlorine in 39 community-tank water samples and 281 rooftop-tank samples was $0.03 \mathrm{mg} / \mathrm{L}$ and $0.02 \mathrm{mg} / \mathrm{L}$, respectively. In Alazzah Camp, the average residual chlorine in 23 community-tank water samples and 100 rooftop-tank samples was $0.13 \mathrm{mg} / \mathrm{L}$ and $0.02 \mathrm{mg} / \mathrm{L}$, respectively. The results in Figure 5 indicate that water samples with the highest concentrations 
of bacteria generally had the lowest concentrations of residual chlorine (as expected). We did not observe a correlation between residual chlorine in the rooftop tanks and either ambient temperature or number of days since the last delivery of water to the camps. Similarly, in Aida Camp, we did not observe a correlation between residual chlorine and elevation or proximity of residences relative to the community tanks. All of the residual chlorine measurements in Aida Camp (both community tank and rooftop tank) were below the $0.2 \mathrm{mg} / \mathrm{L}$ WHO standard; all but three measurements (from the community tank) in Alazzah Camp were below this standard.

\section{Discussion}

Intermittent water supply systems, such as those in Aida Camp and Alazzah Camp, present challenges to water delivery and water quality. Previous reports describe government, consumer, and utility features that are characteristic of intermittent water supply systems, including higher operating costs, accelerated infrastructure deterioration, loss of revenue, and decreased willingness among consumers to pay for services (see review article by Galaitsi et al. [18] and references therein). In intermittent systems, water quality can deteriorate due to physical problems-such as rust formation, pressure surges $[19,20]$, and leaks in the distribution system [21-23]-that arise when pipes are frequently emptied and refilled. Furthermore, because water delivery is intermittent, users typically store water in rooftop tanks to preserve supplies, a practice which, over long periods of time (days), can lead to the growth of bacteria as chlorine residual concentrations decrease [24-26].

As observed by Rusca et al. [27], in regions of intermittent supply, the relationship between political authorities and drinking water quality can become complicated, particularly when officials fail to report data on water quality within distribution systems and water access for high income users is prioritized over low income users. Palestinian refugee camps in the West Bank, which have a distinct political infrastructure from the surrounding communities, appear to be no exception. The camps were established by the UNRWA, which continues to provide basic services to the camps [28], including routine testing of drinking water for bacterial contamination. However, as we observed in Aida Camp and Alazzah Camp, UNRWA testing programs are limited to only a few sites in each camp, and the results are not made available to camp residents (nota bene, nor were the results provided to our research team, despite repeated requests).

We found that $10 \%$ of rooftop-tank water samples $(n=281)$ from Aida Camp contained coliform bacteria. This percentage is similar to that reported by the PWA, which in a 2011 study found that $9.4 \%$ of household tap samples $(n=383)$ from Bethlehem were contaminated with bacteria [29]. In contrast, in Alazzah Camp, we found that only $5 \%$ of rooftop-tank samples were contaminated with bacteria, which may suggest that water quality in Alazzah Camp is generally better than in Bethlehem as a whole. Because the PWA study did not indicate the locations within Bethlehem where the samples were collected, the seasons of sample collection, or the relationships of the households to the broader water supply system, we cannot compare the details of our findings with this previous study.

Our findings suggest the need for additional study to address unanswered questions. For one, we do not know the volume of water added to each of the rooftop tanks when water was being distributed throughout the camps, nor did we measure the volume of water in the tanks at the time of sample collection. Knowing these volumes could yield insights regarding differences in water quality between rooftop tanks. Second, we do not know why rooftop-tank water in Alazzah Camp was generally cleaner than in Aida Camp. We hypothesize it is due to shorter residence times of water in the tanks in Alazzah Camp compared to Aida Camp; however, we did not collect sufficient data to rigorously evaluate this hypothesis. Knowing why rates are lower in Alazzah Camp could help to inform water quality improvement strategies for Aida Camp and possibly other areas in the West Bank. Third, we cannot rule out the possibility that some of the contamination in samples of rooftop-tank water derived from the taps inside the homes as opposed to the tanks themselves. Although we carefully cleaned the taps prior to sample collection, it is possible that our methods did not eliminate all the bacteria within the taps (and pipes upstream of the taps). In addition, it would also be useful to 
more rigorously study the change in rooftop-tank water quality over time. For example, a study in which repeated measurements of bacteria and residual chlorine in selected tanks are made over time could yield important insights into the causes of water quality deterioration.

The overall impact of this study has been generally positive for the two camps in terms of increasing awareness about drinking water quality. Based on the testing results, the Lajee Center has initiated a program to help residents improve the quality of their rooftop-tank water. The program involves free water testing to interested residents, follow-up testing to confirm all positive results, rooftop tank flushing, and point-of-use chlorination (if necessary), as well as educating residents about what the test results mean and how best to improve and preserve drinking water quality.

In summary, we studied the quality of water collected from three locations-community storage tanks, network pipes, and rooftop tanks-in two Palestinian refugee camps in the West Bank. Our results show that water arriving at the camps contains generally low levels of coliform bacteria, but in both camps, water quality deteriorated due to storage in rooftop tanks. The main factor that appears to influence deterioration is ambient temperature and, to a lesser extent, time in storage and the location of the rooftop tanks, relative to the community tank. Our findings are consistent with other studies that have shown water quality deterioration in systems with intermittent water supply. Finally, this study makes clear the necessity of thinking on a policy level about (1) who should ultimately be responsible for maintaining water quality in areas where, in response to water-delivery intermittency, community residents are compelled to store their water in rooftop tanks, and (2) to what extent should users of intermittently supplied water be educated about the risks of long-term water storage. These two questions take on added significance in Palestinian refugee camps where, due to the provisional nature of the camps and how they are governed, it is unlikely that substantial investments in water infrastructure improvements within the camps will be made and that water-supply intermittency will be eliminated.

Author Contributions: The individual contributions of co-authors are as follows: conceptualization, S.A., S.E.G., A.B., N.A.-A. and J.L.D.; methodology, S.A. and J.L.D.; software, S.A. and S.E.G.; validation, S.A. and S.E.G.; formal analysis, S.A. and S.E.G.; resources, J.L.D.; writing-original draft preparation, S.A.; writing-review and editing, S.A., S.E.G., A.B., N.A.-A. and J.L.D.; visualization, S.A. and S.E.G.; supervision, J.L.D.; project administration, S.A. and J.L.D.; funding acquisition, N.A.-A. and J.L.D.

Funding: This study received support from the Water: Systems, Science and Society (WSSS) Program at Tufts University; the Office of the Provost at Tufts University; 1for3.org, a non-profit organization in Winchester (MA, USA) that focusses on issues of water, health, and the environment for Palestinians; and the Lajee Center, a community-based organization in Aida Camp. Open access costs were provided by the Faculty Research Awards Committee at Tufts University.

Acknowledgments: We are grateful to Neelakshi Hudda for help with creating the figures.

Conflicts of Interest: The authors declare no personal conflicts of interest. Although funding for materials and supplies were provided by Tufts University, the Lajee Center, and 1for3.org, these funders played no role in the design of the study; in the collection, analyses or interpretation of data; in the writing of the manuscript, or in the decision to publish the results. 


\section{Appendix A}
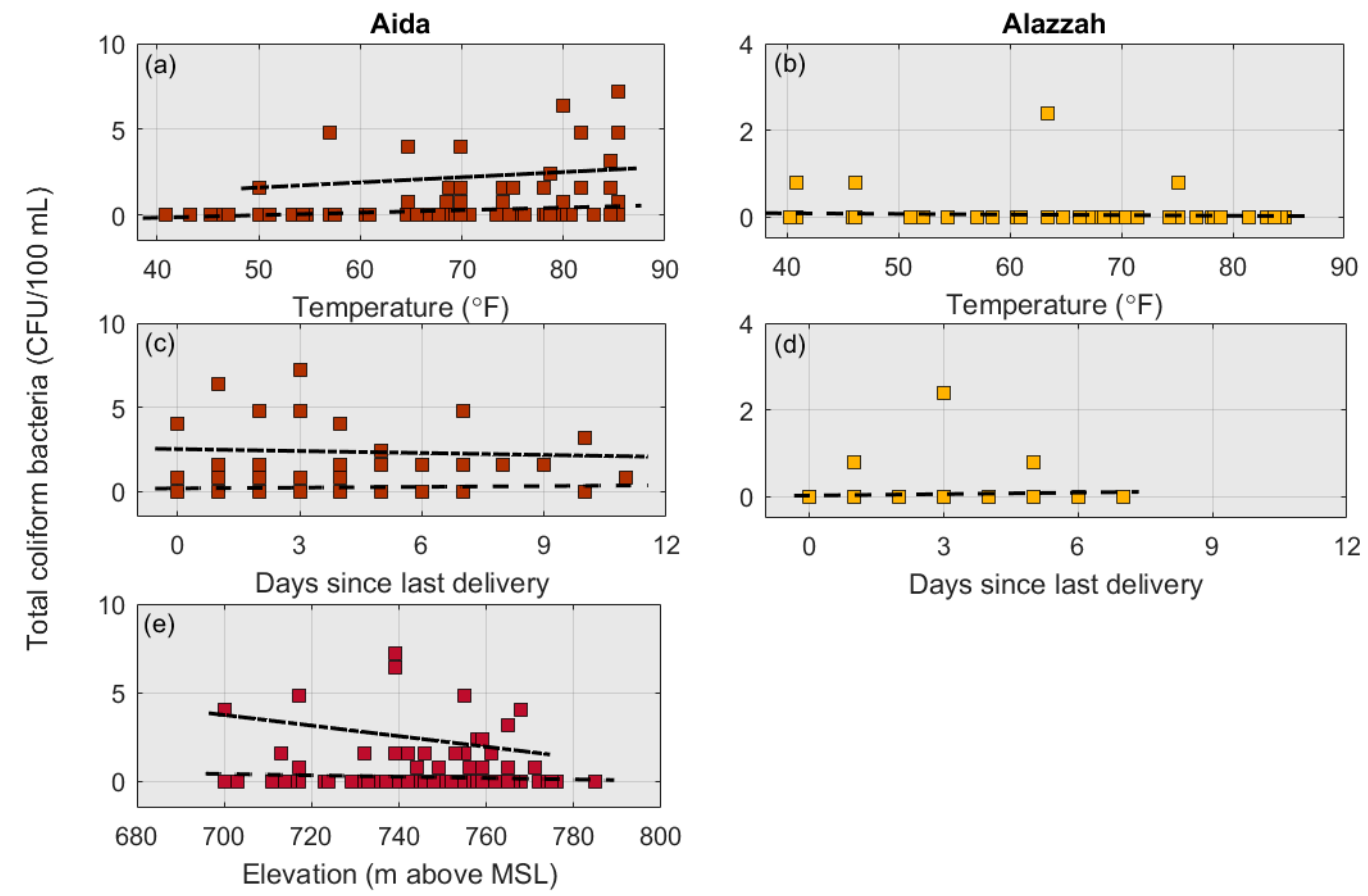

Figure A1. Scatter plots of total coliform bacteria versus $(\mathbf{a}, \mathbf{b})$ air temperature, $(\mathbf{c}, \mathbf{d})$ days since last water delivery to Aida Camp and Alazzah Camp, and (e) house elevation (Aida Camp only) for rooftop-tank samples. Regression lines through all the data are shown with coarsely-dashed lines; regression lines through all the non-zero bacteria data are shown with finely-dashed lines. See Table A1 for summary statistics.

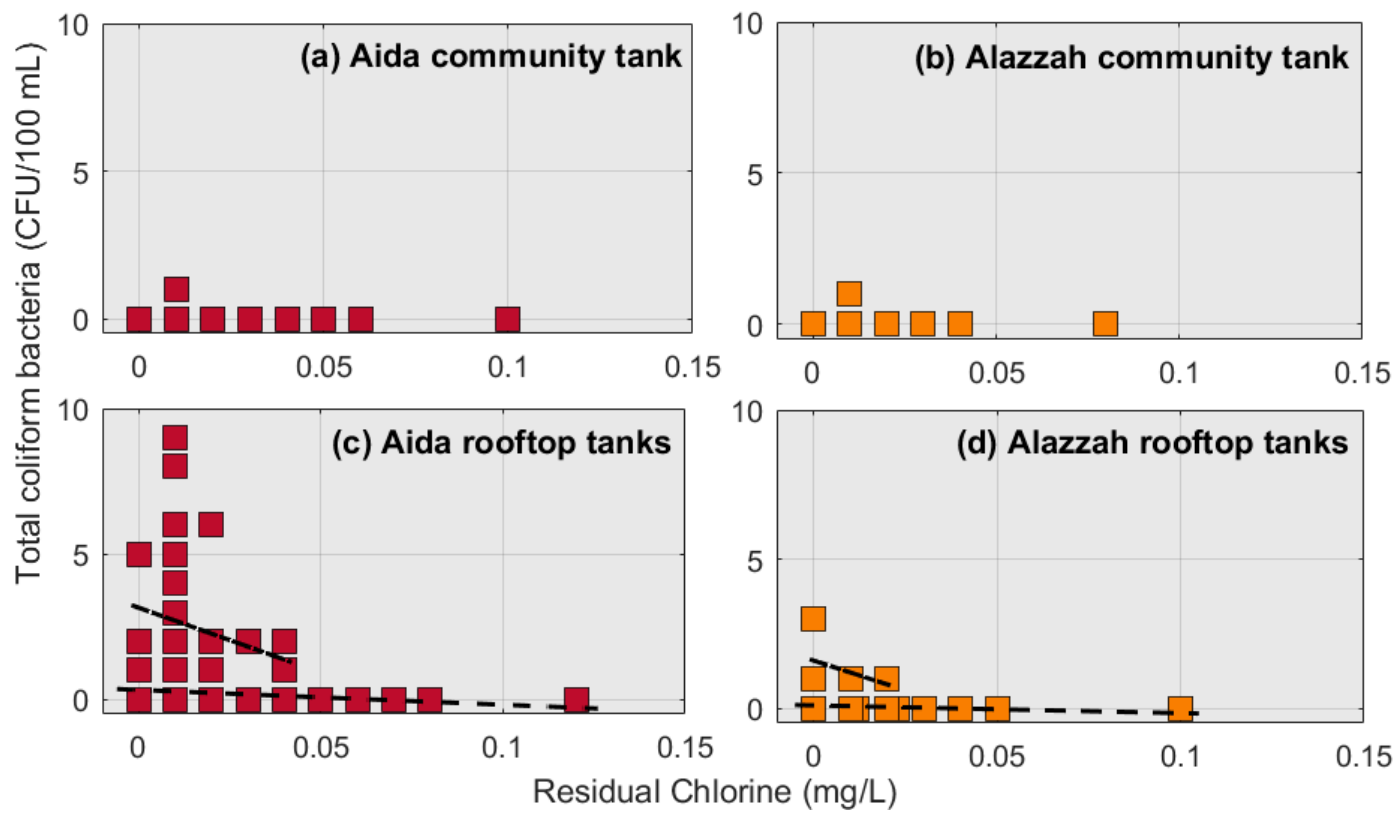

Figure A2. Relationship between bacteria levels (CFU concentrations) and residual free chlorine concentrations in $(\mathbf{a}, \mathbf{b})$ community- and $(\mathbf{c}, \mathbf{d})$ rooftop-tank water samples from Aida Camp and Alazzah Camp. Regression lines through all the data are shown with coarsely-dashed lines; regression lines through all the non-zero bacteria data are shown with finely-dashed lines. See Table A1 for summary statistics. 
Table A1. Regression Statistics for Models in Figures A1 and A2.

\begin{tabular}{|c|c|c|c|c|c|c|c|}
\hline Camp & CFU Data & Co-Variate & Linear Model & SSE & $\mathbf{R}^{2}$ & Adj-R ${ }^{2}$ & RMSE \\
\hline \multirow{8}{*}{ Aida } & All & Res.-Cl & $\begin{aligned} m & =-5.093(-11.17,0.9886) \\
b & =0.3309(0.1659,0.4959)\end{aligned}$ & 219 & 0.0098 & 0.0062 & 0.8915 \\
\hline & All & Temp. & $\begin{aligned} m & =0.01473(0.006681,0.02278) ; \\
b & =-0.7305(-1.269,-0.192)\end{aligned}$ & 230 & 0.0444 & 0.041 & 0.8889 \\
\hline & All & Day & $\begin{array}{c}m=0.01553(-0.02651,0.05757) \\
b=0.1847(0.008882,0.3605)\end{array}$ & 230 & 0.0019 & -0.0017 & 0.9085 \\
\hline & All & Elev. & $\begin{array}{c}m=-0.003834(-0.01033,0.002662) \\
b=3.1(-1.749,7.948)\end{array}$ & 229 & 0.0049 & 0.0013 & 0.9117 \\
\hline & Non-zero & Res.-Cl & $\begin{array}{c}m=-44.51(-103.7,14.63) \\
b=3.153(1.915,4.392)\end{array}$ & 77.9 & 0.0914 & 0.0535 & 1.8019 \\
\hline & Non-zero & Temp. & $\begin{array}{c}m=0.03009(-0.05135,0.1115) \\
b=0.1104(-6.05,6.271)\end{array}$ & 87.0 & 0.0217 & -0.0159 & 1.8293 \\
\hline & Non-zero & Day & $\begin{array}{c}m=-0.03864(-0.2782,0.201) \\
\quad b=2.522(1.345,3.698)\end{array}$ & 88.6 & 0.0042 & -0.0341 & 1.8456 \\
\hline & Non-zero & Elev. & $\begin{array}{c}m=-0.02985(-0.06756,0.007865) \\
b=24.64(-3.503,52.77)\end{array}$ & 80.7 & 0.0924 & 0.0575 & 1.762 \\
\hline \multirow{4}{*}{ Alazzah } & All & Res.-Cl & $\begin{array}{c}m=-2.595(-6.218,1.028) \\
b=0.09436(0.003911,0.1848)\end{array}$ & 6.70 & 0.0228 & -0.0036 & 0.2748 \\
\hline & All & Temp. & $\begin{array}{c}m=-0.001395(-0.00543,0.00264) \\
b=0.1373(-0.1267,0.4012)\end{array}$ & 7.41 & 0.0048 & -0.0054 & 0.2751 \\
\hline & All & Day & $\begin{aligned} m & =0.01132(-0.0167,0.03935) ; \\
b & =0.02037(-0.0671,0.1078)\end{aligned}$ & 7.40 & 0.0065 & -0.0036 & 0.2748 \\
\hline & Non-zero & Res.-Cl & $\begin{array}{c}m=-40(-920.3,840.3) \\
b=1.6(-8.565,11.76)\end{array}$ & 1.28 & 0.25 & -0.5 & 1.131 \\
\hline
\end{tabular}

Notes: CFU Data = all data was used in the regression; non-zero data (positive results only) were used in the regression; Co-variate: Res. $-\mathrm{Cl}=$ residual chlorine concentration; Temp. = ambient temperature; Day = days since last water delivery to the camp; Elev. = ground elevation of residence from which rooftop-tank samples were collected. Linear model: $\mathrm{CFU} / 100 \mathrm{~mL}=m \times$ other variable $+b$ (with $95 \%$ confidence bounds); $m=$ slope of regression line and $b=\mathrm{y}$-axis intercept. SSE $=$ sum of the square due to errors. RMSE $=$ root mean square error.

\section{References}

1. Khair, A.; Mohor, E.A. Access to Water and Wastewater Management in the oPt. 2011. Available online: https:/ / www.arij.org/files/admin/specialreports/waterresource2012.pdf (accessed on 8 January 2018).

2. PWA Water Sector Policy. Water Sector Policy \& Implementation Plan. 2014. Available online: http: / / mwh.gov.jm/Library/Public/Water/DRAFT (accessed on 28 July 2017).

3. Al-Shalalfeh, Z.; Napier, F.; Scandrett, E. Water Nakba in Palestine: Sustainable Development Goal 6 versus Israeli hydro-hegemony. Local Environ. 2018, 23, 117-124. [CrossRef]

4. Galaitsi, S.E.; Huber-Lee, A.; Vogel, R.M.; Naumova, E.N. Using water insecurity to predict domestic water demand in the Palestinian West Bank. Water Int. 2015, 40, 614-634. [CrossRef]

5. World Bank. West Bank and Gaza: Assessment of Restrictions on Palestinian Water Sector Development; World Bank: Washington, DC, USA, 2009.

6. Manenti, C.; Reinicke, C.; MacDonald, J.; Donald, J. Report of a Field Assessment of Health Conditions in the Occupied Palestinian Territory; World Health Organization: Geneva, Switzerland, 2016.

7. Mourad, T.A. Palestinian refugee conditions associated with intestinal parasites and diarrhoea: Nuseirat refugee camp as a case study. Public Health 2004, 118, 131-142. [CrossRef] [PubMed]

8. Issa, M.; McHenry, M.; Issa, A.A.; Blackwood, R.A. Access to safe water and personal hygiene practices in the Kulandia Refugee Camp (Jerusalem). Infect. Dis. Rep. 2015, 7, 6040. [CrossRef] [PubMed]

9. Cabral, J.P. Water microbiology. Bacterial pathogens and water. Int. J. Environ. Res. Public. Health 2010, 7, 3657-3703. [CrossRef] [PubMed]

10. EPA. National Primary Drinking Water Regulations; U.S. Environmental Protection Agency: Washington, DC, USA, 2017. 
11. WHO Guidelines for Drinking-Water Quality: Incorporating 1st and 2nd Addenda, Volume 1, Recommendations. 2008. Available online: https:/ /www.who.int/water_sanitation_health/publications / gdwq3rev/en/ (accessed on 27 January 2019).

12. WHO. A Compendium of Drinking Water Quality Standards in the Eastern Mediterranean Region. Nasser City, Cairo, Eqypt, 2006. Available online: https://apps.who.int/iris/handle/10665/116514 (accessed on 27 January 2019).

13. Sheikhi, R.; Alimohammadi, M.; Askari, M.; Moghaddasian, M.S. Decay of Free Residual Chlorine in Drinking Water at the Point of Use. Iran. J. Public Health 2014, 43, 535. [PubMed]

14. Safe Drinking Water Foundation. What Is Chlorination? Safe Drinking Water Foundation: Saskatoon, SK, Canada. Available online: https:/ / www.safewater.org/fact-sheets-1/2017/1/23/what-is-chlorination (accessed on 23 February 2018).

15. Muslim, A.; Li, Q.; Tadé, M.O. Simulation of free chlorine decay and adaptive chlorine dosing by discrete time-space model for drinking water distribution system. Chem. Prod. Process Model. 2007, 2. [CrossRef]

16. UNRWA. Profile: Aida Camp, Bethlehem Governorate; United Nations Relief and Works Agency for Palestine Refugees in the Near East: East Jerusalem, West Bank, Palestinian Occupied Territory, 2015.

17. LaMotte. Lamotte.com Operator's Manual: SMART Spectro Spectrophotometer. Available online: http://www. lamotte.com/images/pdf/instructions/2000.pdf (accessed on 18 March 2017).

18. Galaitsi, S.; Russell, R.; Bishara, A.; Durant, J.; Bogle, J.; Huber-Lee, A. Intermittent domestic water supply: A critical review and analysis of causal-consequential pathways. Water 2016, 8, 274. [CrossRef]

19. Vairavamoorthy, K.; Gorantiwar, S.D.; Pathirana, A. Managing urban water supplies in developing countries-Climate change and water scarcity scenarios. Phys. Chem. Earth Parts ABC 2008, 33, 330-339. [CrossRef]

20. Kumpel, E.; Nelson, K.L. Comparing microbial water quality in an intermittent and continuous piped water supply. Water Res. 2013, 47, 5176-5188. [CrossRef] [PubMed]

21. Freni, G.; De Marchis, M.; Napoli, E. Implementation of pressure reduction valves in a dynamic water distribution numerical model to control the inequality in water supply. J. Hydroinform. 2014, 16, 207-217. [CrossRef]

22. Goyal, R.V.; Patel, H.M. Analysis of residual chlorine in simple drinking water distribution system with intermittent water supply. Appl. Water Sci. 2015, 5, 311-319. [CrossRef]

23. Taylor, D.D.; Slocum, A.H.; Whittle, A.J. Analytical scaling relations to evaluate leakage and intrusion in intermittent water supply systems. PLoS ONE 2018, 13, e0196887. [CrossRef] [PubMed]

24. Evison, L.; Sunna, N. Microbial regrowth in household water storage tanks. J. Am. Water Works Assoc. 2001, 93, 85-94. [CrossRef]

25. Tokajian, S.; Hashwa, F. Water quality problems associated with intermittent water supply. Water Sci. Technol. 2003, 47, 229-234. [CrossRef] [PubMed]

26. Hashwa, F.; Tokajian, S. Intermittent Water Supply and Domestic Water Quality in the Middle East. In Water in the Middle East and in North Africa; Springer: Berlin, Germany, 2004; pp. 157-166.

27. Rusca, M.; Boakye-Ansah, A.S.; Loftus, A.; Ferrero, G.; van der Zaag, P. An interdisciplinary political ecology of drinking water quality. Exploring socio-ecological inequalities in Lilongwe's water supply network. Geoforum 2017, 84, 138-146. [CrossRef]

28. Feldman, I. Life Lived in Relief: Humanitarian Predicaments and Palestinian Refugee Politics; University of California Press: Berkeley, CA, USA, 2018.

29. Palestinian Water Authority. Annual Status Report on Water Resources, Water Supply, and Wastewater in the Occupied State of Palestine 2011; Palestinian Water Authority: Ramallah, West Bank, Palestinian Authority, 2012.

(C) 2019 by the authors. Licensee MDPI, Basel, Switzerland. This article is an open access article distributed under the terms and conditions of the Creative Commons Attribution (CC BY) license (http://creativecommons.org/licenses/by/4.0/). 